\title{
Communication Skills in Practice
}

\author{
Muhammad Khaled Al-Alawneh \\ Yarmouk University \\ Irbid, Jordan \\ Mahir Shafeeq Hawamleh \\ Al al-Bayt University \\ Al-Mafraq, Jordan \\ Dina AH Al-Jamal and Ghada Suleiman Sasa \\ Yarmouk University \\ Irbid, Jordan
}

\begin{abstract}
This study aimed at infusing top-notch communication skills, among students enrolled at Effective Communication Skills course. The course is elective for all Yarmouk University specialties (viz. medicine, art, science...etc.) for the academic year 2017/2018. A descriptive analytical research design was followed by the means of a survey questionnaire administered randomly on 546 students in order to assess their repository of effective communication skills. The study reported significant impact on participants' personal traits, social and presentation skills and on their relations with the others. This effectiveness was not affected by factors of gender or academic year.
\end{abstract}

Keywords: Communication skills; Yarmouk University; Jordan.

\section{Introduction}

Communication skills are the qualities required for achieving goals that include personal and interpersonal qualities and social abilities. Such skills are referred to as 'soft' because they are comparable to sentiments or visions that enable individuals to "read" others. These skills are required in workplace as almost all careers require engagement or interaction with others in a way or in another (Gioiosa \& Kinkela, 2019; Al- Eiadeh, Al-Sobh, Al-Zoubi, \& Al-Khasawneh, 2016; Nitonde, 2014; Harlak, Gemalmaz, Gurel, Dereboy, \& Ertekin, 2008; Cleland, Foster, and Moffat, 2005; Hagmann, 2002). These skills are crucial for any human action. It's true that some individuals are born with the ability to communicate; but others need more efforts to make it feasible. In higher education institutions, very often, students only develop their academic attainment without any consideration of their 'soft skills'. 
Any effective and meaningful interaction among individuals is referred to as communication. Very often, it follows some plain stages such as: purpose creation, composing, encoding, transmission, decoding and lastly interpretation of the message by the addressee (Novik, 2015; Gooden \& Kearns, 2013; Mischel \& Shoda, 2008; McKay, Davis \& Fanning, 1995). The features of communication take in quite a lot of details. These details reflect the nature of communication as a 2-way process which incorporates sending and receiving messages. Such 2way process is active, lively and complex as it varies in light of the level of reaching the designated shared appreciation, in which communicators not only give-and-take ideas and feelings but also construct meaning. So, sharing is a key feature of effective communication. Of course, sharing involves using a code through the initiation of a message by a sender, by the means of a channel, to a receiver. Here, noise is very much expected. Nevertheless, feedback is a crucial element in communication as encourages \discourages the continuation of communication. Definitely, communication is irreversible, that is, a communicator can't retract what has been said verbally or indicated nonverbally (Mahajan, 2015; Seema, 2012; Bruner, 1960).

Communication has several functions that are sometimes steered towards modifying or even changing in behaviour. Specifically, communication is held to share feelings and thoughts for several purposes that aim to connect with others such as: inspiring, motivating, making orders, entertaining, directing, controlling, informing, educating (Muste, 2016; Keyton, 2011). Communication can't be effective with one form excluding the other; that is both forms of communication (verbal and nonverbal) are extremely needed to carry out communication successfully. These forms are further segmented into either spoken \vocal or non-vocal \gestures; for example, presentations, meetings, job interviews, and emails. Very much often, paralinguistic characteristics like stress, intonation, volume, passion, and rate convey different types of meanings without involving words per se. Body language, further, adds substantial meanings by opting for the appropriate sensing of facial expression, posture, or any gesture. Both verbal and non-verbal communication need to be consistent (Muste, 2016; Mahajan, 2015; Prasad, 2014; Hasson, 2012; Wilson \& Nias, 1999) Much of the roles of universities were stated by Castells (2001) as steered towards shaping ideologies, building knowledge, making research, and preparing graduates for workplace. To Castells, these roles are pertinent to all countries.

It is possible that most, if not all, effective communication skills are central to teaching and learning at university level. Generally, tutors not only like students who can perform well in the subject matter, but also who can share their study reflections plainly and effectively. Tutors perceptions on students can be related to their communication capability to communicate (Gooden \& Kearns, 2013; Mischel \& Shoda, 2008; McKay, Davis \& Fanning, 1995; Burns, 1985). Self-esteem is enhanced by effective communication skills; as individuals become more confident once interconnecting vocally or non-vocally in or outside the lecture hall, similarly, the manner they perform discussions and presentations. Here, 
they thrive as they predict their success, so, their self-fulfilling insight influences the manner they perform (Adler, Rosenfeld, \& Proctor, 2010).

Earlier research on communication skills among university students has reported the significance learning of such skills. Worldwide examples demonstrate the latter. Let's say in California, Kim and Wright (1989) mapped community college students' and employers' perceptions on abilities needed most for workplace. 2,330 participant students and 306 participant employers responded to a 46-workplace skill survey questionnaire. The study reported that interpersonal skills, communication skills, and problem solving are exclusively essential in workplace. Similarly in Romania, Iordache -Platis and Josan (2009) evaluated the communication competence within Romanian universities and proposed conducts to improve such competence in line with European Union competence. Findings asserted the significant role of university as a trigger for amendment and development in culture and society. In Hong Kong, however, Bankowski (2010) trained students, enrolled at English for Academic Purposes (EAP) course, on oral presentations skills. Findings revealed that presentation skill training helped students to perform research, understand themes, speak to audience, use formats and structures, and to that end motivated them to embrace different ways of study.

Correspondingly as part of a greater scale study on Language and Social Cohesion in the Formation of National Identity sponsored by University Kebangsaan in Malaysia, Idris, Hassan, Ya'acob \& Gill, (2012) investigated the roles of universities in shaping the national identity of the youth; where 375 individuals took part and filled in a survey questionnaire. Results asserted the crucial role of universities in development of national identity. Nevertheless, In Brazil, Feitosa, Del Prette \& Del Prette (2012) examined the relationship between social skills and academic ability. 80 male and female students were assessed by three tests; namely: intelligence test, social skills test and an achievement test (viz. SAT). Findings established that cognitive competence enables social skills to develop students' academic attainment. In the same vein in Philippines, Comedis (2014) ascertained the relationship of De La Salle Araneta university students' social skills with their academic ability. A correlational research design was followed as to correlate 103 sociology freshman students' academic ability with their social skills of: cooperation, assertiveness, empathy and selfcontrol for two successive years. Findings revealed that self-control and whole social skills improved students' academic ability.

In Malaysia, Mey, Abdullah and Yin (2014) summarized and observed personality traits of graduate and undergraduate research university students. The authors followed a quantitative research design of personality traits by the means of the Behavioral Management Information System (BeMIS) to hold distinction, novelty and vitality measures. Findings confirmed that students' personality profile helped them to handle the formal change; as their personality turns out to be extra powerfully expressed and developed during the change phases. Likewise in Australia, Schurer, Kassenboehmer and Leung (2015) examined the role of universities in shaping graduates' personality in light of 
human capital investment model. The participants, 369 youth, were examined throughout eight years. Findings pinpointed that university does not form graduates who have a strong personality qualities in terms of ethics or intelligence. Nevertheless, it fades as they get older. In the same vein in Saudi Arabia, Ismail et al. (2016) investigated 941 students university students' "personality" who are enrolled in dissimilar departments of five different universities. To collect data, retrospective and extracurricular activities to help students develop their personalities (Big Fives). Findings were crystal clear concerning the effectiveness of the given activities in assisting students build their potentials in leadership in addition to sport.

Another example comes from Romania, Simona (2015) considered foreign language skills along with communication kills as crucial for engineering career in knowledge community. 100 students took part in the study. Data were collected by interviews containing replicated job interviews together with case study analyses. Findings confirmed that presentation skills in English assisted students to achieve their career ends. Likewise in Ghana, Asemanyi (2015) investigated the reasons behind students' low achievement in, Communication Skills course at the University of Education, Winneba, in order to publicize recommendations on its teaching and learning. The sample consisted of 35 students and 5 lectures who are concerned with the course under study. To collect data, interviews, observations, and documents were used. Findings revealed students' negative attitudes towards the course because of language incompetency, lack of facilities related to the lecture hall, and irregular meetings devoted to the course.

\section{Context}

Higher education institutions can take part in equipping graduates with social and work skills along with academic one. Here, over the last three semesters, Yarmouk University, a Jordanian public university, added Effective Communication Skills as a basic skills course as a prerequisite for graduation. Upon graduation, communication skills are central particularly throughout job interviews. Now, the researchers had the opportunity to teach this course for three successive semesters. Actually, its teaching has a palpable passion for fostering effective communication that may change their own world when it comes to different settings inside or outside the lecture hall. In this way, universities can support and improve communities.

This study is significant as communication skills assessment obtained by the current study was taken further in proposing teaching guideline for Communication Skills course. This study is limited to the analysis of communication forms that embrace verbal and non-verbal communication. Specifically, the surveyed top-notch communication categories included personal traits, social and presentation skills and relations with others. Furthermore, the study limits its generalization of the findings to students at public universities, in Jordan, in the academic year of 2017/2018. 


\section{Purpose and Questions}

The present study aimed at infusing top-notch communicative skills among university students and evaluates students' use of such skills. In order to fulfil the purposes of the study, the present study answered the following two questions:

1- To what extent, if any, does Effective Communication Skills course develop university students' top-notch communication skills?

2- Are there any significant differences between students' responses due to the variables (gender, level of the study, type of colleges, nature of the course, and the usefulness of the course) regarding the effect of the course on their communication skills?

\section{Methodology}

This study aligns with the vision and the mission of Yarmouk University which to equip students with pedagogical, behavioural, skills, and experiences to enhance students' abilities that qualify them to lead in the workplace. Communication skill is considered one of these skills that assist student to be prepared for the employment process. Today, employers need graduates who can present, interview, and work in team.

A high percentage of students who were enrolled in the communication skills course in the academic year 2017-2018 participated in this study. The total number was 959 students distributed into 15 sections taught by 11 instructors from the college of education, department of curriculum and instruction. The Questionnaires distributed to the all participants, however, the number of returned questionnaire was 566 as rate of return 59\%. The sample is the population of the study per se; thereby all students who were enrolled Effective Communication Skills were selected. There were 546 students after the researchers excluded 20 questionnaires for the pilot study. Table 1 shows the demographic variables of the students who participated in the study.

Table 1: Demographic of Sample by Gender, Academic Year, and Type of College

\begin{tabular}{llll}
\hline IV and its Levels & & Frequency & $\%$ \\
\hline Gender & Male & 203 & 37.18 \\
& Female & 343 & 62.82 \\
& Total & 546 & 100.00 \\
\hline Academic Year & First & 121 & 22.16 \\
& Second & 212 & 38.83 \\
& Third & 112 & 20.51 \\
& Fourth & 84 & 15.38 \\
& Fifth & 17 & 3.11 \\
& Total & 546 & 100.00 \\
\hline Faculty & Scientific & 328 & 60.07 \\
& Humanities & 218 & 39.93 \\
& Total & 546 & 100.00 \\
\hline Nature of Subject & Theoretic & 177 & 32.42 \\
& Practical & 33 & 6.04 \\
& Theoretic and Practical & 336 & 61.54 \\
& Total & 546 & 100.00 \\
\hline
\end{tabular}




\begin{tabular}{llll} 
Usefulness of Subject & Little & 38 & 6.96 \\
& Great & 203 & 37.18 \\
& Very Great & 305 & 55.86 \\
& Total & 546 & 100.00 \\
\hline
\end{tabular}

Table 1 also shows students' perspectives toward the nature of the subject (course), and their perspectives toward the usefulness of the communication skills course that they attended. In terms of the demographic variables, about two-third (343) of the participants were female students. A notable number (212) are in their second year of study. Moreover, the number of the students who participated from scientific colleges was (328) versus (218) from social sciences and humanities colleges. In terms of the students' perspectives toward the nature of the course, about $61 \%$ of the participants reported that the course is presented in a mixed method (theoretical and practical). In terms of the usefulness of the course, about $56 \%$ of the participants rated the course they attend as "Very Great".

\section{Instrumentation and procedures}

The data for this study was collected by a questionnaire that developed by the researchers based on the previous literature. The questionnaire was divided into three sections: the first section was instructions for the participants, the second section was the demographic data of the participants, and the third section was the study's dimensions which includes 36 items distributed into four domains; specifically, the impact of the course on the relations with the others (17 items), the impact of the course on the personal traits (6 items), social skills (6 items), and presentation skills (7 items).

Concerning the procedures of the study, theoretical and practical literature was reviewed; then various communication strategies were identified. After that, appropriate time for class depends on the communication skill stage was allocated. In the first meeting, the students' attention was drawn to the skills under the study. In the following meetings (number 20 hours), the participants, who got their permission signed, were taught the skills. In the last meeting, they filled in the survey questionnaire.

\section{Validity and Reliability}

The questionnaire was tested for reliability and validity. In terms of validity, to make sure that this instrument measures what it has developed for, three types of validity were applied: Facial, construction, and content validity. The validity was tested by 12 faculty members who are specialized in social education, science education, vocational education, management and economy, psychology and measurement, educational technology, and workforce education and development. Table 2 shows the construct validity. 
Table 2: Instrument's Construct Validity

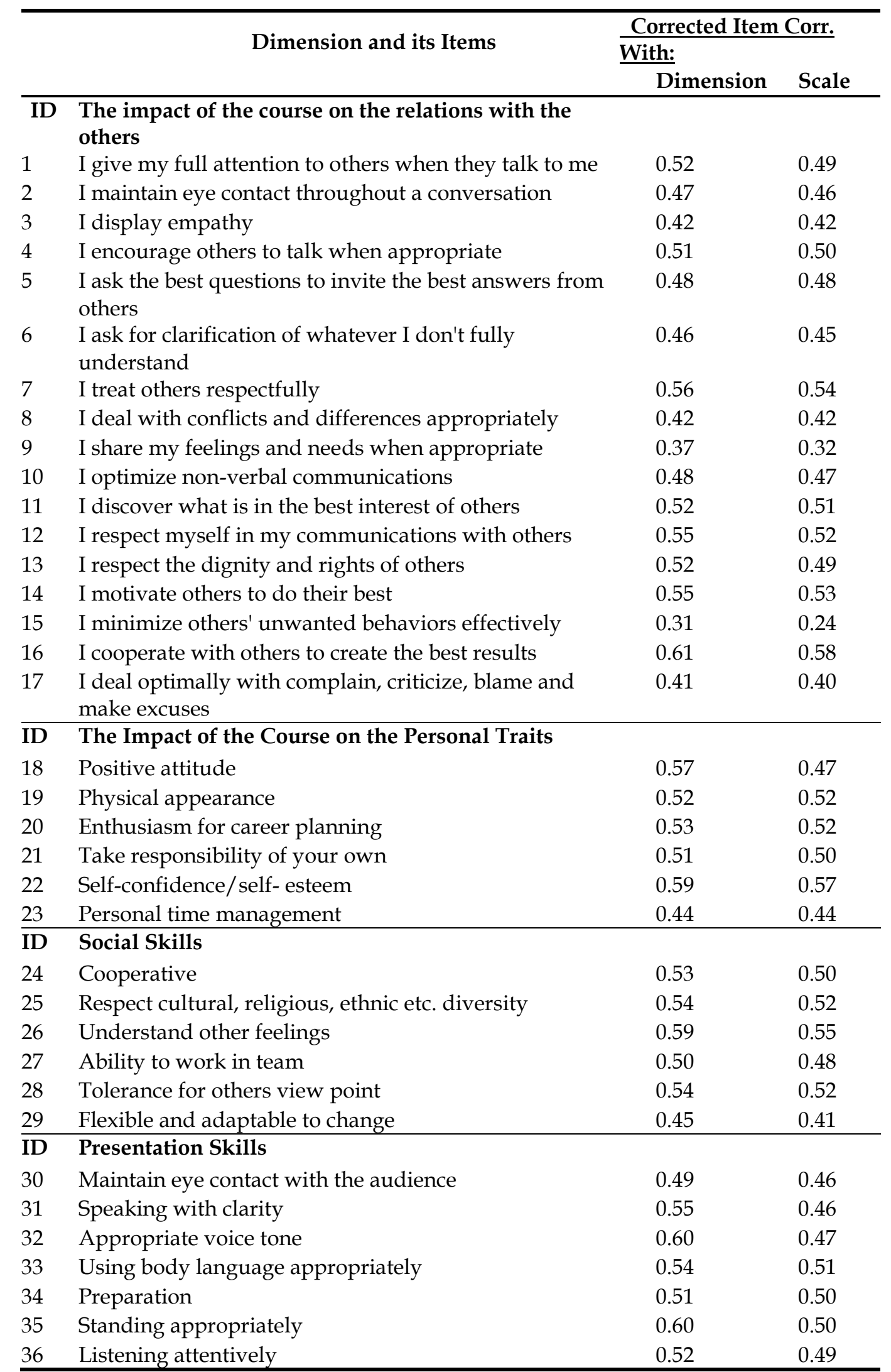


Table 2 shows the correlation within the items and with each item and the whole scale. The lowest correlation within items was (0.31) and the lowest for the whole scale was $(0.24)$ for the item "I minimize others' unwanted behaviors effectively". However, the highest correlation within the items was (0.61), and the correlation for the whole scale was $(0.58)$ for the item "I cooperate with others to create the best results ". Furthermore, the internal construction validity was calculated to reveal the correlation within and between the instrument's domains as presented in Table 3.

Table 3: Overall Correlations for the Domains and the Scale

\begin{tabular}{llllll}
\hline $\begin{array}{l}\text { Correlation } \\
\text { Among }\end{array}$ & Statistic & $\begin{array}{l}\text { The impact } \\
\text { relations } \\
\text { with the } \\
\text { others }\end{array}$ & $\begin{array}{l}\text { The Impact } \\
\text { on the } \\
\text { Personal } \\
\text { Traits }\end{array}$ & $\begin{array}{l}\text { Social } \\
\text { Skills }\end{array}$ & $\begin{array}{l}\text { Presentation } \\
\text { Skills }\end{array}$ \\
\hline The Impact on the Personal & $P$ & $\mathbf{0 . 6 6}$ & & & \\
Traits & Sig. & 0.00 & & & \\
\hline Social Skills & $P$ & $\mathbf{0 . 6 7}$ & $\mathbf{0 . 6 1}$ & & \\
& Sig. & 0.00 & 0.00 & & \\
\hline Presentation Skills & $P$ & $\mathbf{0 . 5 9}$ & $\mathbf{0 . 6 3}$ & $\mathbf{0 . 6 0}$ & \\
& Sig. & 0.00 & 0.00 & 0.00 & \\
\hline WHOLE SCALE & $P$ & $\mathbf{0 . 9 2}$ & $\mathbf{0 . 8 2}$ & $\mathbf{0 . 8 2}$ & $\mathbf{0 . 8 0}$ \\
& Sig. & 0.00 & 0.00 & 0.00 & 0.00 \\
\hline
\end{tabular}

Table 3 shows that the correlation between the impact of the course on the relations with others and the impact of the course on the personal traits was 0.66 , the correlation between the impact of the course on the personal traits and social skills was 0.61 , the correlation between social skills and presentation skills was 0.60 , and the correlation for the whole scale with the four domains ranged between 0.80 and 0.92 . Moreover, reliability was tested using responses from 546 students. The Cronbach's Alpha reliability was 0.92 and the Stability index for the entire questionnaire 36 items was 0.83 . Table 4 shows the Cronbach's Alpha Coefficient for the scale and its domains $(n=546)$.

Table 4: Cronbach's Alpha Coefficient for the Scale and its Domains $(n=546)$

\begin{tabular}{llll}
\hline Scale and its Dimensions & $\begin{array}{l}\text { Cronbach' } \\
\text { s } \\
\text { Alpha }\end{array}$ & $\begin{array}{l}\text { Stabilit } \\
\mathbf{y} \\
\text { Index }\end{array}$ & $\begin{array}{l}\text { N of } \\
\text { Item } \\
\text { s }\end{array}$ \\
\hline $\begin{array}{l}\text { The impact of the course on the relations with the } \\
\text { others }\end{array}$ & 0.85 & $\mathbf{0 . 8 1}$ & 17 \\
The Impact of the Course on the Personal Traits & 0.76 & $\mathbf{0 . 8 9}$ & 6 \\
Social Skills & 0.76 & $\mathbf{0 . 8 8}$ & 6 \\
Presentation Skills & 0.80 & $\mathbf{0 . 8 5}$ & 7 \\
\hline Whole Scale & 0.92 & $\mathbf{0 . 8 0}$ & 36 \\
\hline
\end{tabular}

\section{Data Collection}

The researchers distributed the questionnaire to all students who were enrolled in Effective Communication Skills class in the first semester 2017-2018. Specifically, in the 15 involved sections, students were informed about the nature of the study and the instructions on how to respond to the questionnaire. The 
researchers obtained permission from all the 15 instructors and their students to apply this study. Students have been selected based on their interest to participate.

\section{Results}

This study was conducted to explore the impact of Effective Communication Skills course on students' personal traits, social skills, presentation skills, and their relation with the others. This section exhibits results in light of the questions of the study respectively.

\section{Communication skills development}

The first question reads as: to what extent, if any, does Effective Communication Skills course develop university students' communication skills? Table 5 shows Yarmouk University's students perception toward effective communication skills course.

Table 5: Students' Perspectives toward the Impact of the Communication Skills Course

\begin{tabular}{|c|c|c|c|c|c|}
\hline Rank & $\mathbf{I D}$ & Scaleandits Dimensions & Mean & Std.Dev. & Degree \\
\hline 1 & 2 & The Impact of the Course on the Personal Traits & 3.54 & 0.44 & High \\
\hline 2 & 3 & Social Skills & 3.47 & 0.44 & High \\
\hline 3 & 4 & Presentation Skills & 3.45 & 0.45 & High \\
\hline 4 & 1 & $\begin{array}{l}\text { The impact of the course on the relations with the } \\
\text { others }\end{array}$ & 3.37 & 0.38 & High \\
\hline \multicolumn{3}{|c|}{ Whole Scale } & 3.43 & 0.35 & High \\
\hline
\end{tabular}

Table 5 shows the means and standard deviations of the four domains. The impact of the course on the personal traits was ranked "high" at the top with $\mathrm{M}=3.54$, whereas the impact of the course on the relations with the others was ranked at the bottom of the list with $\mathrm{M}=3.37$. However, the social skills ranked at the second place with $\mathrm{M}=3.47$ and the presentation skills ranked in the third place with $\mathrm{M}=3.45$. The whole scale was ranked "high" as well.

Table 6: Means and Standard Deviations of the Impact of the Course on the Relations with Others

\begin{tabular}{llllll}
\hline Rank & ID & $\begin{array}{l}\text { Items of the impact of the } \\
\text { course on the personal traits }\end{array}$ & Mean & $\begin{array}{l}\text { Std. } \\
\text { Dev. }\end{array}$ & Degree \\
\hline 1 & 19 & Physical appearance & 3.68 & 0.58 & High \\
2 & 22 & Self-confidence/self-esteem & 3.61 & 0.62 & High \\
3 & 20 & Enthusiasm for career planning & 3.58 & 0.68 & High \\
4 & 18 & Positive attitude & 3.47 & 0.63 & High \\
5 & 21 & Take responsibility of your own & 3.47 & 0.65 & High \\
6 & 23 & Personal time management & 3.42 & 0.71 & High \\
\hline
\end{tabular}

Table 6 shows that all items were ranked "high". The item "physical appearance" ranked at the top of the items in this domain. However, the item "personal time management" was ranked at the bottom of the items. In terms of the impact of the course on the social skills, Table 7 shows the mean and standard deviations on social skills. 
Table 7: Means and Standard Deviations of the Impact of the Course on Social Skills

\begin{tabular}{llllll}
\hline Rank & ID & Items of social skills & Mean & $\begin{array}{l}\text { Std. } \\
\text { Dev. }\end{array}$ & Degree \\
\hline 1 & 25 & Respect cultural, religious, ethnic etc. diversity & 3.68 & 0.58 & High \\
2 & 26 & Understand other feelings & 3.53 & 0.66 & High \\
3 & 24 & Cooperative & 3.44 & 0.63 & High \\
4 & 27 & Ability to work in team & 3.44 & 0.69 & High \\
5 & 28 & Tolerance for others view point & 3.41 & 0.66 & High \\
6 & 29 & Flexible and adaptable to change & 3.30 & 0.70 & High \\
\hline
\end{tabular}

Table 7 shows that the item "Respect cultural, religious, ethnic etc. diversity" was ranked at the top of the list, nevertheless, the item "flexible and adaptable to change" was ranked at the bottom of the list in this domain. In terms of the presentation skills, Table 8 shows the students perspectives toward the impact of this course on their presentation skills.

Table 8: Means and Standard Deviations of the Students' Perspectives on Presentation Skills

\begin{tabular}{llllll}
\hline Rank & ID & Items of presentation skills & Mean & $\begin{array}{l}\text { Std. } \\
\text { Dev. }\end{array}$ & Degree \\
\hline 1 & 36 & Listening attentively & 3.54 & 0.66 & High \\
2 & 32 & Appropriate voice tone & 3.52 & 0.67 & High \\
3 & 31 & Speaking with clarity & 3.49 & 0.65 & High \\
4 & 34 & Preparation & 3.47 & 0.70 & High \\
5 & 35 & Standing appropriately & 3.47 & 0.66 & High \\
6 & 33 & Using body language appropriately & 3.38 & 0.71 & High \\
7 & 30 & Maintain eye contact with the audience & 3.28 & 0.71 & High \\
\hline
\end{tabular}

Table 8 shows that the all items of presentation skills were ranked "high". The item "listening attentively" was ranked at the top of the items in this domain. Whereas, the item "maintain eye contact with the audience" was ranked at the bottom of the items. Concerning the impact of the course on the relations with the others, Table 9 shows the means and the standard deviations of the students' perspectives in this domain.

Table 9: Means and Standard Deviations of Impact of the Course on the Relations with the Others

\begin{tabular}{lllccl}
\hline Rank & ID & $\begin{array}{l}\text { Items of theimpact of course } \\
\text { on the relations with the others }\end{array}$ & Mean & $\begin{array}{l}\text { Std. } \\
\text { Dev. }\end{array}$ & Degree \\
\hline 1 & 13 & I respect the dignity and rights of others & 3.77 & 0.51 & High \\
2 & 7 & I treat others respectfully & 3.73 & 0.57 & High \\
3 & 12 & $\begin{array}{l}\text { I respect myself in my communications with } \\
\text { others }\end{array}$ & 3.71 & 0.57 & High \\
4 & 14 & I motivate others to do their best & 3.51 & 0.64 & High \\
5 & 4 & I encourage others to talk when appropriate & 3.45 & 0.70 & High \\
6 & 1 & I give my full attention to others when they talk & 3.43 & 0.61 & High \\
7 & 3 & to me & 3.40 & 0.72 & High \\
8 & 2 & I display empathy & 3.36 & 0.66 & High
\end{tabular}




\begin{tabular}{|c|c|c|c|c|c|}
\hline & & conversation & & & \\
\hline 9 & 11 & I discover what is in the best interest of others & 3.36 & 0.69 & High \\
\hline 10 & 16 & I cooperate with others to create the best results & 3.35 & 0.69 & High \\
\hline 11 & 8 & $\begin{array}{l}\text { I deal with conflicts and differences } \\
\text { appropriately }\end{array}$ & 3.33 & 0.65 & High \\
\hline 12 & 5 & $\begin{array}{l}\text { I ask the best questions to invite the best } \\
\text { answers from others }\end{array}$ & 3.32 & 0.70 & High \\
\hline 13 & 10 & I optimize non-verbal communications & 3.32 & 0.75 & High \\
\hline 14 & 6 & $\begin{array}{l}\text { I ask for clarification of whatever I don't fully } \\
\text { understand }\end{array}$ & 3.30 & 0.75 & High \\
\hline 15 & 17 & $\begin{array}{l}\text { I deal optimally with complain, criticize, blame } \\
\text { and make excuses }\end{array}$ & 3.05 & 0.81 & High \\
\hline 16 & 9 & I share my feelings and needs when appropriate & 2.97 & 0.91 & Moderate \\
\hline 17 & 15 & $\begin{array}{l}\text { I minimize others' unwanted behaviours } \\
\text { effectively }\end{array}$ & 2.92 & 0.85 & Moderate \\
\hline
\end{tabular}

Table 9 shows the means and standard deviations of the students' perspectives on the impact of the course on the relations with others. Item (13) "I respect the dignity and rights of others" was ranked "high" at the top of the domains' items, whereas, item (15) "I minimize others' unwanted behaviors effectively" was ranked "moderate" at the bottom of this domain.

\section{Students' Variables and Communication Skills}

The second question reads as: Are there any significant differences between students' responses due to the variables (gender, level of the study, type of colleges, nature of the course, and the usefulness of the course) regarding the effect of the course on their communication skills? To answer this question, the means and the standard deviations was calculated to find the impact of the course on the relations with the others, on the personal traits, on the social skills, and on the presentation skills as Table 10 shows.

Table 10: Means and Standard Deviations of impact of the Course on the Students' Communication Skills based on the Independence Variables

\begin{tabular}{|c|c|c|c|c|c|c|c|c|}
\hline \multirow[b]{2}{*}{ Dimensions } & \multirow[b]{2}{*}{ IV } & \multirow{2}{*}{$\begin{array}{l}\text { Levels } \\
\text { of IV }\end{array}$} & \multirow[b]{2}{*}{ Mean } & \multirow{2}{*}{$\begin{array}{l}\text { Std. } \\
\text { Dev. }\end{array}$} & \multirow{2}{*}{$\begin{array}{l}\text { Adj. } \\
\text { Mean }\end{array}$} & \multirow[b]{2}{*}{$\begin{array}{l}\text { Std. } \\
\text { Error }\end{array}$} & \multicolumn{2}{|c|}{ 95\% C.I. } \\
\hline & & & & & & & L.B. & U.B \\
\hline \multirow{12}{*}{$\begin{array}{l}\text { The impact } \\
\text { of } \\
\text { the course } \\
\text { on } \\
\text { the relations } \\
\text { with the } \\
\text { others }\end{array}$} & \multirow[t]{2}{*}{ Gender } & Male & 3.32 & 0.42 & 3.24 & 0.04 & 3.16 & 3.31 \\
\hline & & Female & 3.40 & 0.35 & 3.28 & 0.04 & 3.21 & 3.36 \\
\hline & \multirow{5}{*}{$\begin{array}{l}\text { Academic } \\
\text { Year }\end{array}$} & First & 3.42 & 0.32 & 3.33 & 0.04 & 3.25 & 3.41 \\
\hline & & Second & 3.36 & 0.41 & 3.26 & 0.03 & 3.19 & 3.33 \\
\hline & & Third & 3.34 & 0.38 & 3.26 & 0.04 & 3.17 & 3.34 \\
\hline & & Fourth & 3.36 & 0.38 & 3.23 & 0.05 & 3.14 & 3.32 \\
\hline & & Fifth & 3.34 & 0.26 & 3.22 & 0.09 & 3.04 & 3.40 \\
\hline & \multirow[t]{2}{*}{ Faculty } & Scientific & 3.36 & 0.37 & 3.25 & 0.03 & 3.18 & 3.32 \\
\hline & & Humanities & 3.38 & 0.38 & 3.27 & 0.04 & 3.19 & 3.34 \\
\hline & \multirow{3}{*}{$\begin{array}{l}\text { Nature of } \\
\text { the Course }\end{array}$} & Theoretic & 3.37 & 0.38 & 3.30 & 0.03 & 3.24 & 3.37 \\
\hline & & Practical & 3.32 & 0.38 & 3.21 & 0.07 & 3.08 & 3.34 \\
\hline & & $\begin{array}{l}\text { Theoretic } \\
\text { and } \\
\text { Practical }\end{array}$ & 3.38 & 0.38 & 3.26 & 0.03 & 3.20 & 3.32 \\
\hline
\end{tabular}




\begin{tabular}{|c|c|c|c|c|c|c|c|c|}
\hline \multirow[b]{2}{*}{ Dimensions } & \multirow[b]{2}{*}{ IV } & \multirow{2}{*}{$\begin{array}{l}\text { Levels } \\
\text { of IV }\end{array}$} & \multirow[b]{2}{*}{ Mean } & \multirow{2}{*}{$\begin{array}{l}\text { Std. } \\
\text { Dev. }\end{array}$} & \multirow{2}{*}{$\begin{array}{l}\text { Adj. } \\
\text { Mean }\end{array}$} & \multirow{2}{*}{$\begin{array}{l}\text { Std. } \\
\text { Error }\end{array}$} & \multicolumn{2}{|c|}{ 95\% C.I. } \\
\hline & & & & & & & L.B. & U.B \\
\hline & Usefulness & Little & 3.16 & 0.53 & 3.12 & 0.06 & 3.00 & 3.24 \\
\hline & of the & Great & 3.23 & 0.32 & 3.20 & 0.03 & 3.13 & 3.27 \\
\hline & Course & Very Great & 3.49 & 0.35 & 3.46 & 0.03 & 3.40 & 3.53 \\
\hline & Total & & 3.37 & 0.38 & 3.26 & 0.03 & 3.20 & 3.32 \\
\hline \multirow{16}{*}{$\begin{array}{l}\text { The Impact } \\
\text { of } \\
\text { the Course } \\
\text { on } \\
\text { the Personal } \\
\text { Traits }\end{array}$} & \multirow[t]{2}{*}{ Gender } & Male & 3.52 & 0.47 & 3.47 & 0.04 & 3.38 & 3.55 \\
\hline & & Female & 3.55 & 0.42 & 3.49 & 0.04 & 3.40 & 3.57 \\
\hline & Academic & First & 3.60 & 0.37 & 3.55 & 0.05 & 3.45 & 3.64 \\
\hline & \multirow[t]{4}{*}{ Year } & Second & 3.52 & 0.47 & 3.46 & 0.04 & 3.38 & 3.54 \\
\hline & & Third & 3.55 & 0.43 & 3.49 & 0.05 & 3.39 & 3.59 \\
\hline & & Fourth & 3.47 & 0.46 & 3.38 & 0.05 & 3.28 & 3.49 \\
\hline & & Fifth & 3.60 & 0.35 & 3.51 & 0.11 & 3.30 & 3.73 \\
\hline & \multirow[t]{2}{*}{ Faculty } & Scientific & 3.53 & 0.44 & 3.46 & 0.04 & 3.38 & 3.54 \\
\hline & & Humanities & 3.56 & 0.43 & 3.50 & 0.05 & 3.41 & 3.58 \\
\hline & \multirow{3}{*}{$\begin{array}{l}\text { Nature of } \\
\text { the Course }\end{array}$} & Theoretic & 3.50 & 0.47 & 3.47 & 0.04 & 3.39 & 3.55 \\
\hline & & Practical & 3.56 & 0.44 & 3.50 & 0.08 & 3.34 & 3.65 \\
\hline & & $\begin{array}{l}\text { Theoretic } \\
\text { and } \\
\text { Practical }\end{array}$ & 3.56 & 0.42 & 3.47 & 0.04 & 3.40 & 3.54 \\
\hline & \multirow{3}{*}{$\begin{array}{l}\text { Usefulness } \\
\text { of the } \\
\text { Course }\end{array}$} & Little & 3.34 & 0.60 & 3.35 & 0.08 & 3.20 & 3.49 \\
\hline & & Great & 3.44 & 0.40 & 3.44 & 0.04 & 3.36 & 3.52 \\
\hline & & Very Great & 3.63 & 0.41 & 3.65 & 0.04 & 3.57 & 3.72 \\
\hline & Total & & 3.54 & 0.44 & 3.48 & 0.04 & 3.40 & 3.56 \\
\hline \multirow{16}{*}{$\begin{array}{l}\text { Social } \\
\text { Skills }\end{array}$} & \multirow[t]{2}{*}{ Gender } & Male & 3.41 & 0.50 & 3.35 & 0.05 & 3.26 & 3.44 \\
\hline & & Female & 3.50 & 0.40 & 3.42 & 0.04 & 3.34 & 3.51 \\
\hline & Academic & First & 3.50 & 0.39 & 3.45 & 0.05 & 3.35 & 3.55 \\
\hline & \multirow{4}{*}{ Year } & Second & 3.47 & 0.45 & 3.42 & 0.04 & 3.34 & 3.50 \\
\hline & & Third & 3.42 & 0.46 & 3.37 & 0.05 & 3.27 & 3.47 \\
\hline & & Fourth & 3.49 & 0.41 & 3.41 & 0.06 & 3.30 & 3.52 \\
\hline & & Fifth & 3.32 & 0.59 & 3.28 & 0.11 & 3.06 & 3.50 \\
\hline & \multirow[t]{2}{*}{ Faculty } & Scientific & 3.46 & 0.43 & 3.38 & 0.04 & 3.30 & 3.47 \\
\hline & & Humanities & 3.47 & 0.45 & 3.39 & 0.05 & 3.30 & 3.48 \\
\hline & \multirow{3}{*}{$\begin{array}{l}\text { Nature of } \\
\text { the Course }\end{array}$} & Theoretic & 3.45 & 0.45 & 3.38 & 0.04 & 3.30 & 3.46 \\
\hline & & Practical & 3.52 & 0.39 & 3.42 & 0.08 & 3.26 & 3.58 \\
\hline & & $\begin{array}{l}\text { Theoretic } \\
\text { and } \\
\text { Practical }\end{array}$ & 3.47 & 0.44 & 3.37 & 0.04 & 3.29 & 3.44 \\
\hline & \multirow{3}{*}{$\begin{array}{l}\text { Usefulness } \\
\text { of the } \\
\text { Course }\end{array}$} & Little & 3.30 & 0.53 & 3.42 & 0.04 & 3.33 & 3.50 \\
\hline & & Great & 3.38 & 0.39 & 3.28 & 0.08 & 3.12 & 3.45 \\
\hline & & Very Great & 3.54 & 0.45 & 3.39 & 0.04 & 3.32 & 3.47 \\
\hline & Total & & 3.47 & 0.44 & 3.39 & 0.04 & 3.31 & 3.47 \\
\hline \multirow{8}{*}{$\begin{array}{l}\text { Presentation } \\
\text { Skills }\end{array}$} & \multirow[t]{2}{*}{ Gender } & Male & 3.43 & 0.46 & 3.36 & 0.05 & 3.27 & 3.45 \\
\hline & & Female & 3.46 & 0.45 & 3.37 & 0.05 & 3.28 & 3.46 \\
\hline & Academic & First & 3.45 & 0.42 & 3.37 & 0.05 & 3.27 & 3.47 \\
\hline & Year & Second & 3.46 & 0.46 & 3.37 & 0.04 & 3.28 & 3.45 \\
\hline & & Third & 3.46 & 0.46 & 3.38 & 0.05 & 3.28 & 3.48 \\
\hline & & Fourth & 3.39 & 0.48 & 3.28 & 0.06 & 3.17 & 3.40 \\
\hline & & Fifth & 3.54 & 0.32 & 3.42 & 0.11 & 3.20 & 3.64 \\
\hline & Faculty & Scientific & 3.42 & 0.45 & 3.32 & 0.04 & 3.23 & 3.41 \\
\hline
\end{tabular}




\begin{tabular}{|c|c|c|c|c|c|c|c|c|}
\hline \multirow[b]{2}{*}{ Dimensions } & \multirow[b]{2}{*}{ IV } & \multirow{2}{*}{$\begin{array}{l}\text { Levels } \\
\text { of IV }\end{array}$} & \multirow[b]{2}{*}{ Mean } & \multirow{2}{*}{$\begin{array}{l}\text { Std. } \\
\text { Dev. }\end{array}$} & \multirow{2}{*}{$\begin{array}{l}\text { Adj. } \\
\text { Mean }\end{array}$} & \multirow{2}{*}{$\begin{array}{l}\text { Std. } \\
\text { Error }\end{array}$} & \multicolumn{2}{|c|}{ 95\% C.I. } \\
\hline & & & & & & & L.B. & U.B \\
\hline & & Humanities & 3.50 & 0.45 & 3.41 & 0.05 & 3.32 & 3.50 \\
\hline & Nature of & Theoretic & 3.44 & 0.44 & 3.28 & 0.08 & 3.13 & 3.43 \\
\hline & the Course & Practical & 3.33 & 0.53 & 3.36 & 0.04 & 3.28 & 3.45 \\
\hline & & $\begin{array}{l}\text { Theoretic } \\
\text { and } \\
\text { Practical }\end{array}$ & 3.47 & 0.45 & 3.52 & 0.04 & 3.45 & 3.60 \\
\hline & Usefulness & Little & 3.27 & 0.40 & 3.23 & 0.08 & 3.08 & 3.39 \\
\hline & of the & Great & 3.36 & 0.41 & 3.34 & 0.04 & 3.25 & 3.43 \\
\hline & Course & Very Great & 3.53 & 0.47 & 3.52 & 0.04 & 3.44 & 3.60 \\
\hline & Total & & 3.45 & 0.45 & 3.37 & 0.04 & 3.28 & 3.45 \\
\hline \multirow[t]{15}{*}{ Total } & \multirow[t]{2}{*}{ Gender } & Male & 3.42 & 0.46 & 3.35 & 0.04 & 3.28 & 3.43 \\
\hline & & Female & 3.48 & 0.40 & 3.39 & 0.04 & 3.32 & 3.46 \\
\hline & \multirow{5}{*}{$\begin{array}{l}\text { Academic } \\
\text { Year }\end{array}$} & First & 3.49 & 0.37 & 3.43 & 0.04 & 3.35 & 3.50 \\
\hline & & Second & 3.45 & 0.45 & 3.38 & 0.03 & 3.31 & 3.44 \\
\hline & & Third & 3.44 & 0.43 & 3.38 & 0.04 & 3.29 & 3.46 \\
\hline & & Fourth & 3.43 & 0.43 & 3.33 & 0.04 & 3.24 & 3.41 \\
\hline & & Fifth & 3.45 & 0.38 & 3.36 & 0.09 & 3.18 & 3.53 \\
\hline & \multirow[t]{2}{*}{ Faculty } & Scientific & 3.44 & 0.42 & 3.35 & 0.03 & 3.29 & 3.42 \\
\hline & & Humanities & 3.48 & 0.43 & 3.39 & 0.04 & 3.32 & 3.46 \\
\hline & \multirow{3}{*}{$\begin{array}{l}\text { Nature of } \\
\text { the Course }\end{array}$} & Theoretic & 3.44 & 0.44 & 3.39 & 0.03 & 3.33 & 3.46 \\
\hline & & Practical & 3.43 & 0.43 & 3.35 & 0.07 & 3.22 & 3.48 \\
\hline & & $\begin{array}{l}\text { Theoretic } \\
\text { and } \\
\text { Practical }\end{array}$ & 3.47 & 0.42 & 3.37 & 0.03 & 3.32 & 3.43 \\
\hline & \multirow{3}{*}{$\begin{array}{l}\text { Usefulness } \\
\text { of } \\
\text { the Course }\end{array}$} & Little & 3.27 & 0.51 & 3.24 & 0.06 & 3.12 & 3.37 \\
\hline & & Great & 3.35 & 0.38 & 3.34 & 0.03 & 3.27 & 3.40 \\
\hline & & Very Great & 3.55 & 0.42 & 3.54 & 0.03 & 3.48 & 3.60 \\
\hline
\end{tabular}

Table 10 shows that there are significant differences between the mean scores regarding the impact of the communication skills course on the students based on the variables (gender, level of study, type of the college, nature of the course, and the usefulness of the course). To make sure that the differences are real, the researchers run a 7-way mixed ANOVA with one within-subject and with six between-groups to explore the impact of the course on personal traits, social skills, presentation skills, and on the relations with others. Table 11 shows the 7way mixed ANOVA.

Table 11: Seven-Way Mixed ANOVA in the Mean Scores between and within Groups

\begin{tabular}{|c|c|c|c|c|c|c|}
\hline $\begin{array}{l}\text { Tests of } \\
\text { Effects }\end{array}$ & $\begin{array}{l}\text { Source of } \\
\text { Variance }\end{array}$ & $\begin{array}{l}\text { Sum of } \\
\text { Squares }\end{array}$ & df & $\begin{array}{l}\text { Mean } \\
\text { Square }\end{array}$ & $\mathbf{F}$ & Sig. \\
\hline \multicolumn{7}{|c|}{$\begin{array}{l}\text { Within-the Subjects [Mauchly's W(0.95); Approx. } \chi^{2}(30.07) ; d f(5) ; \operatorname{Sig}(0.00) ; \varepsilon_{(G r e e n h o u s e} \\
\text { Geisser) }(0.97)]\end{array}$} \\
\hline & Dimensions & 2.78 & 2.90 & 0.96 & 13.61 & 0.00 \\
\hline & Dimensions $\times$ Gender & 0.30 & 2.90 & 0.10 & 1.45 & 0.23 \\
\hline & $\begin{array}{l}\text { Dimensions } \times \text { Academic } \\
\text { Year }\end{array}$ & 1.38 & 11.60 & 0.12 & 1.70 & 0.06 \\
\hline
\end{tabular}




\begin{tabular}{|c|c|c|c|c|c|c|}
\hline & Dimensions×Faculty & 0.56 & 2.90 & 0.19 & 2.73 & 0.04 \\
\hline & $\begin{array}{l}\text { Dimensions } \times \text { Nature of } \\
\text { the Course }\end{array}$ & 0.70 & 5.80 & 0.12 & 1.71 & 0.12 \\
\hline & $\begin{array}{l}\text { Dimensions } \times \text { Usefulnes } \\
\mathrm{s} \text { of the Course }\end{array}$ & 0.78 & 5.80 & 0.13 & 1.91 & 0.08 \\
\hline & Error(Dimensions) & 109.12 & $\begin{array}{l}1551.2 \\
2\end{array}$ & 0.07 & & \\
\hline & Total & 115.61 & $\begin{array}{l}1583.1 \\
1\end{array}$ & 0.07 & & \\
\hline \multicolumn{7}{|c|}{ Between-the Subjects } \\
\hline & Gender & 0.72 & 1.00 & 0.72 & 1.51 & 0.22 \\
\hline & Academic Year & 1.95 & 4.00 & 0.49 & 1.02 & 0.40 \\
\hline & Faculty & 0.68 & 1.00 & 0.68 & 1.41 & 0.24 \\
\hline & Nature of the Course & 0.23 & 2.00 & 0.12 & 0.24 & 0.79 \\
\hline & $\begin{array}{l}\text { Usefulness of the } \\
\text { Course }\end{array}$ & 25.28 & 2.00 & 12.64 & 26.33 & 0.00 \\
\hline & Error & 256.84 & 535.00 & 0.48 & & \\
\hline & Total & 285.70 & 545.00 & 0.52 & & \\
\hline Total & & 401.31 & $\begin{array}{l}2128.1 \\
1\end{array}$ & 0.19 & & \\
\hline
\end{tabular}

Table 11 shows that there are significant differences (at $a=0.05$ ) in the mean scores based on the communication skills domains, as the impact of the course on the students comes on multi levels, the researchers applied Bonferroni post hoc test between mean scores as Table 12 shows.

Table 12: Bonferroni Post Hoc Test between the Mean Scores based on Communication Skills Dimensions

\begin{tabular}{lcccc}
\hline Dimensions & & $\begin{array}{c}\text { The impact of the course } \\
\text { on the relations with the } \\
\text { others }\end{array}$ & $\begin{array}{c}\text { Presentation } \\
\text { Skills }\end{array}$ & $\begin{array}{c}\text { Social } \\
\text { Skills }\end{array}$ \\
\hline Bonferroni $\}$ & $\begin{array}{c}\text { Adj. } \\
\text { Mean }\end{array}$ & 3.26 & 3.37 & 3.39 \\
\hline $\begin{array}{l}\text { Presentation Skills } \\
\text { Social Skills }\end{array}$ & 3.37 & $\mathbf{0 . 1 0}$ & & \\
$\begin{array}{l}\text { The impact of the course } \\
\text { on the Personal Traits }\end{array}$ & 3.39 & $\mathbf{0 . 1 3}$ & 0.02 & \\
\hline
\end{tabular}

Evidently as displayed in Table 12, the real differences between the mean scores regarding the impacts of the course on the students' communication skills domains came in the following order: a) the impact of the course on the personal traits, b) the impact of the course on the social skills, c) the impact of the course on the presentation skills. Table 11 shows that there are no significant differences $(a=0.05)$ between the mean scores regarding the impact of the course on interaction of the dimensions with the variable (gender). Also, Table 12 shows that there are no significant differences $(\alpha=0.05)$ between the mean scores regarding the impact of the course (personal traits, social skills, presentation skills) due to the interaction the variable ( level of study). Moreover, table 12 shows that there are no significant differences $(\alpha=0.05)$ between the mean scores 
regarding the impact of the course (personal traits, social skills, presentation skills) due to the interaction the variable (type of the college) as Figure 1 shows.

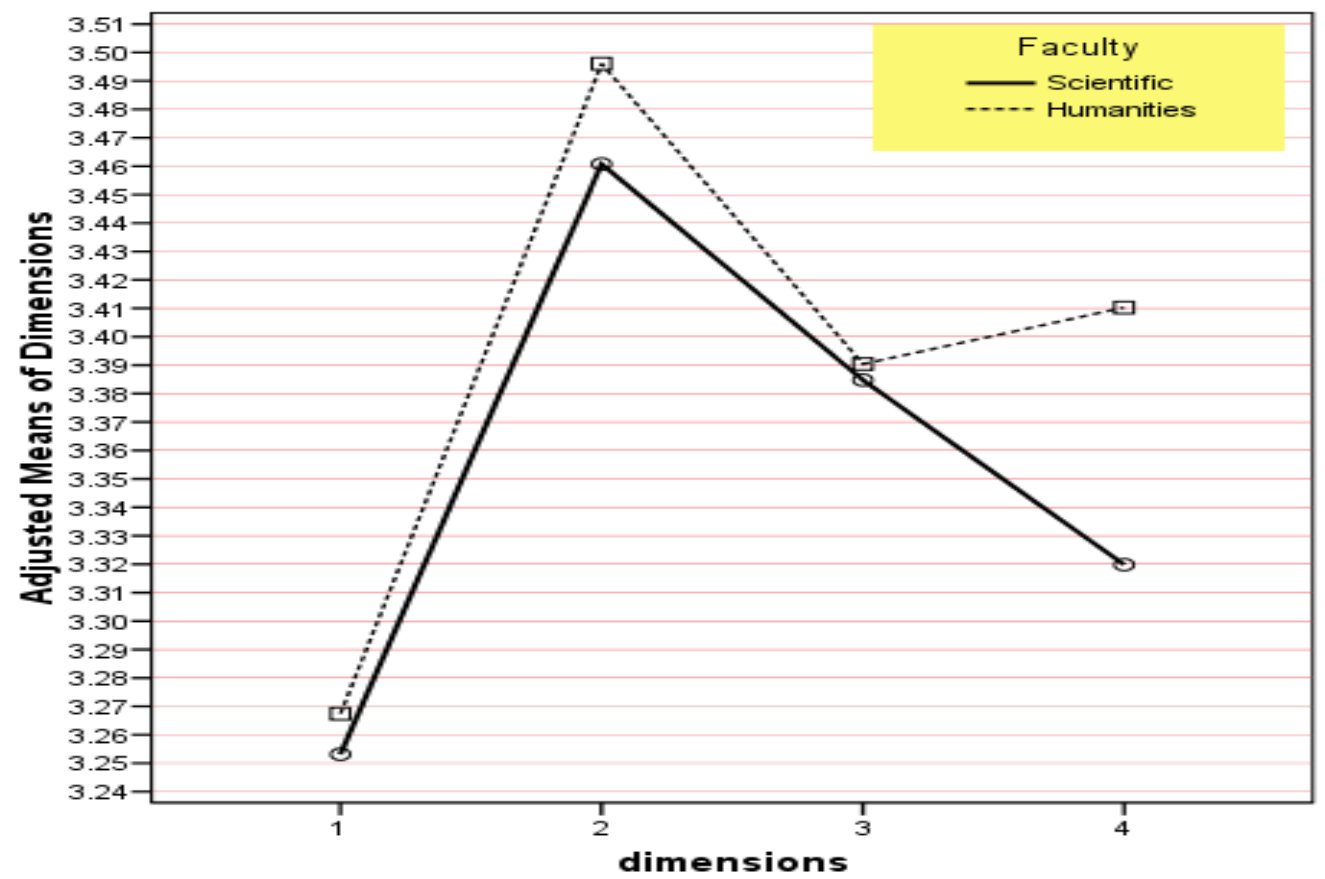

Figure 1: Ordinal Interaction of the Mean Scores of the Impact of the Course on the Students based on the College Type

Figure 1 shows that the impact of the four-dimension of the communication skills on the students from humanity colleges was higher than their colleagues in the scientific colleges and the impact was notable in two of the communication skills domains (the impact of the course on the personal traits and presentation skills). Also, Figure 1 shows that the impact of the course on the students from humanity colleges came developing according to mean scores: The impact of the course on the relations with the others, Social Skills, Presentation Skills, and the impact of the course on the Personal Traits. However, for the students form the scientific colleges, the ascending order was: The impact of the course on the relations with the others, Presentation Skills, Social Skills, and the impact of the course on the Personal Traits. Finally, the impact of the course on the students from the humanity colleges was higher than the impact of the course on the students from the scientific colleges at $(\alpha=0.05)$.

\section{Discussion}

Uuniversity setting is very demanding as it entails students to have an acceptable level of personal traits, social skills, presentation skills, and relation with others. In practice, improved communication abilities were perceived by the participants in the current study. One possible contributor to the effectiveness of this course may be relevant to its applied mode of delivery, rather than a theoretical lecture manner. In consequence, students' perception of 
the success of the course under the study was reported as high signifying their satisfaction as well as attainment of the intended aims of the course. This result is in congruence with Rider and Keefer (2006) who similarly recommended functional demonstrations of communication skills.

Another explanation, of the obtained perception of the great effect of the course on students' communication, may be contributed to tutors' focus on not only the plain components of communication, but also on how communication occurs and why it occasionally fails. This is in accordance with Shannon's Theory Model (1948). According to this sender-message-receiver model, the context where communicating takes place in, is very significant and thereby an informative source of info. For that reason, interaction between tutors and students is boundless. Or possibly, class interactions are always fruitful where meaning is shared between the tutor and the student; actions and responses signal effective established connections. These include a sender and a receiver through the means of a channel (Mahajan, 2015).

The effectiveness of development of communication skills may be touched by students' variables as each student has his/her own personal traits; thus evaluating communication skills can't be far from demographic factors (Doganay \& Keskin, 2008). The results obtained from the analysis revealed how these variables affected students' communication ability.

Research shows that students held contrasting views concerning gendered communication. Some say that females are better in communication than males (e.g. Holmes, 1995); others say the opposite (Lakoff, 1973). Nevertheless, the present study demonstrated an impact on both. This may be attribute to the nondefensive kind of communication held in classes. In all taught sections, the tutors defined communicative situations while acknowledging the students' feelings (be empathetic). The researchers believe that the course is properly delivered because of the tutors in focus believe that communication is fruitful whenever it is indirect and non-defensive.

In this study, students' perceptions towards the significance of communication skills were great to a large extent. This signals the likeliness of developing communication skills over suitable activities. In the same vein, Ihmeideh, AlOmari and Al-Dababneh (2010) who asserted that constructive communication settings afford more prospects for effective communication.

\section{Conclusions and Recommendations}

This study explored the effects of infusing top-notch communication skills on university students. Here, effective communication encompasses not only being thoughtful to talk plainly and absolutely, but also valuing others and paying attention to what others share. In conclusion, the study found out that:

- Students' responses showed their feelings of bonding with their tutors.

- Infusing communication skills among university students is likely to inspire their personal, academic and social exchanges. 
- Effective communication is a combination of verbal and non-verbal communication.

- Students' personal traits, social skills, presentation skills, and relations with others were the top-notch skills imparted the participants in this study.

- This course demonstrated confident perceptions effectiveness which will, in turn, has a societal impact through the discovery of opportunities to create social change.

The findings gained in this study may give insight to some recommendations which are beneficial for university context as it can improve the condition and status of effective communication for undergraduates. Students, who can communicate well, are responsible for their own learning and become more confident about their communication ability. This can be best achieved through being alert who lets the students complete what they started saying. Of course, attending students' non-verbal language is crucial for encouraging the scaffolding of their ideas.

\section{References}

Adler, R. B., Rosenfeld, L. B., \& Proctor, R. F. (2010). Interplay: The process of interpersonal communication. New York: Oxford University Press.

Al-Eiadeh, A-R., Al-Sobh, M. A., Al-Zoubi, S. M., \& Al-Khasawneh, F. (2016). Improving English language speaking skills of Ajloun National University students. International Journal of English and Education. 5(I3), 181-195.

Asemanyi, Abena Abokoma (2015). An assessment of students' performance in communication skills: A case study of the university of education. Journal of Education and Practice, 6(35).

Bankowski, E. (2010). Developing skills for effective academic presentations in EAP. International Journal of Teaching and Learning in Higher Education, 22(2), 187-196.

Bruner, J. S. (1960). The process of education. Harvard University, Cambridge, Massuchusetts. doi:10.1002/bs.3830090108

Burns, D. D. (1985). Intimate Connections. New York: Signet (Penguin Books).

Castells, M. (2001). Universities as dynamic systems of contradictory functions in J. Muller et al. (eds) Challenges of globalisation. South African debates with Manuel Castells, (pp. 206-223). Cape Town: Maskew Miller Longman.

Cleland, J., Foster, K., \& Moffat, M. (2005). Undergraduate students' attitudes to communication skills learning differ depending on year of study and gender. Medical Teacher, 27(3), 246-251. doi:10.1080/01421590400029541

Comedis, J. E. (2014). The role of social skills in the academic performance of De La Salle Araneta University freshmen students: Creating a culture. The DLSU Research Congress, De La Salle University, Manila, Philippines.

Doganay, U., \& Keskin, F. (2008). A study on the interpersonal communication education in Turkey. Culture and Communication, 11(1), 9-32.

Feitosa, F. B., Del Prette, Z. A. P., \& Del Prette, A. (2012). Social skills and academic achievement: The mediating function of cognitive competence. Temas em Psicologia 20(1), 61-70.

Gioiosa, M. E., \& Kinkela, K. (2019). Classroom exercises with technology and communication skills: Students' perceptions. Journal of International Education in Business. 12(1), 2-13. doi:10.1108/JIEB-02-2018-0005. 
Gooden, C., \& Kearns, J. (2013). The importance of communication skills in young children. Research Brief, Human Development Institute, University of Kentucky. Retrieved from http://www.hdi.uky.edu/media/default/documents/research/researchbrief_s ummer2013.pdf

Hagmann, J. (2002). Competence development in soft skills/personal mastery. Report on design of a learning programme at Makerere University, Uganda, Rockefeller Foundation, Nairobi.

Harlak, H., Gemalmaz, A., Gurel, F. S., Dereboy, C., \& Ertekin, K. (2008). Communication skills training: Effects on attitudes toward communication skills and empathic tendency. Education for Health: Change in Learning and Practice, 21(2), 62.

Hasson, Gill. (2012). Brilliant communication skills. Great Britain: Pearson Education.

Holmes, Janet (1995). Women, Men and Politeness. London: Longman. doi:10.1017/S0272263100015278

Idris, F., Hassan, Z., Ya'acob, A., \& Gill, S. K. (2012).The role of education in shaping youth's national identity. Procedia - Social and Behavioral Sciences, 59, 443-450.

Ihmeideh, F. M., Al-Omari, A. A., \& Al-Dababneh, K. A. (2010). Attitude toward communication skills among students' teachers' in Jordanian Public Universities. Australian Journal of Teacher Education, 35(4). doi:10.14221/ajte.2010v35n4.1

Iordache-Platis, M., \& Josan, I. (2009). Communication efficiency within higher education institutions: The case of Romania. European Research Studies, XII(2), 55-66.

Ismail, M., Nadeem, M., Thind, M. H. H., Shaheen, M. A., Shahid, M., \& Ahmad, R. (2016). Role of ECA's (Extra Curricular Activities) in Personality Development. International Journal of Research Studies in Biosciences, 4(11), 47-56. Retrieved from https://www.arcjournals.org/pdfs/ijrsb/v4-i11/8.pdf

Keyton, J. (2011). Communication and organizational culture: A key to understanding work experience. Thousand Oaks, CA: Sage.

Kim, Y., \& Wright, C. E. (1989). A study of general education requirements in vocational education programs. Menlo Park, CA: Educational Evaluation and Research. (ERIC) Document Reproduction Service No. ED 312482.

Lakoff, R. (1973). Language and women's place. Language in Society, 2(1), 45-80. doi:10.1017/S0047404500000051

Mahajan, R. (2015). The Key role of communication skills in the life of professionals. IOSR Journal of Humanities and Social Science (IOSR-JHSS), 20(12), 36-39. doi:10.9790/0837-201223639

McKay, M., Davis, M., \& Fanning, P. (1995). Messages: The communication skills book. Oakland, CA: New Harbinger.

Mey, S. Ch., Abdullah, M. N. L. Y., \& Yin, C. J. (2014). Profiling the personality traits of University undergraduate and postgraduate students at a research university in Malaysia. The Professional Counsellor, 4(4), 378-389. doi:10.15241/scm.4.4.378

Mischel, W., \& Shoda, Y. (2008). Towards a unified theory of personality: integrating dispositions and processing dynamics within the cognitive-affective processing system. In L. A. Pervin, O. P. John \& R. W. Robins (Eds.) Handbook of Personality: Theory and research (pp. 208-241). New York: The Guilford Press.

Muste, D. (2016). The Role of Communication Skills in Teaching Process. Selection and peer-review under responsibility of the Organizing Committee of the conference. The European Proceedings of Behavioral and Social Sciences EpSBS.

Nitonde, Rohidas (2014). Soft skills and personality development. Paper presented at the National Level Seminar on Soft Skills and Personality Development. Retrieved from

https://www.researchgate.net/publication/269390471_Soft_Skills_and_Persona lity_Development 
Novik N. N. (2015). A model of developing communication skills among adolescents with behavioral problems. International Journal of Environmental $\mathcal{E}$ Science Education, 10(4), 579-587. doi:10.12973/ijese.2015.272a.

Prasad, P. (2014). The functional aspects of communication skills. New Delhi: S. K. Kataria \& Sons.

Rider, E. A., \& Keefer, C. (2006). Communication skills competencies: definitions and a teaching toolbox. Medical Education, 40(7), 624-629. doi:10.1111/j.13652929.2006.02500.x

Schurer, S., Kassenboehmer, S. C., \& Leung, F. (2015). Do universities shape their students' personality? Discussion Paper No. 8873, Germany. Retrieved from http://ftp.iza.org/dp8873.pdf

Seema, G. (2012). Emotional intelligence in classroom, Advances in Management, 5(10), 1625.

Shannon, C. E. A. (1948). Mathematical theory of communication. The Bell System Technical Journal, 27(1), 379-423. doi:10.1002/j.1538-7305.1948.tb01338.x

Simona, C. E. (2015). Developing presentation skills in the English language courses for the engineering students of the 21st century knowledge society. Procedia - Social and Behavioral Sciences, 203, 69-74. doi.10.1016/j.sbspro.2015.08.261

Wilson, G., \& Nias, D. (1999). Beauty can't be beat. In L. Guerrero and J. DeVito, (Eds.) The nonverbal communication reader: Classic and contemporary readings. Prospect Heights, IL: Waveland Press. 